\title{
Keeping a Completely Autotrophic Nitrogen Removal over Nitrite System Effective in Treating Low Ammonium Wastewater by Adopting an Alternative Low and High Ammonium Influent Regime
}

\author{
Qinglong Chang, Weigang Wang, Jie Chen, and Yayi Wang \\ State Key Laboratory of Pollution Control and Resources Reuse, College of Environmental Science and Engineering, \\ Tongji University, Siping Road, Shanghai 200092, China
}

Correspondence should be addressed to Yayi Wang; yayi.wang@tongji.edu.cn

Received 19 January 2018; Accepted 6 March 2018; Published 17 April 2018

Academic Editor: Shijian Ge

Copyright (C) 2018 Qinglong Chang et al. This is an open access article distributed under the Creative Commons Attribution License, which permits unrestricted use, distribution, and reproduction in any medium, provided the original work is properly cited.

\begin{abstract}
An alternative low and high ammonium influent regime was proposed and adopted to keep a completely autotrophic nitrogen removal over nitrite (CANON) effective when treating low ammonium wastewater. Results show that, by cyclic operating at an alternative low and high ammonium concentration for 10 days and 28 days, the CANON system could effectively treat low ammonium wastewater. Excessive proliferation of nitrite oxidizing bacteria (NOB) under low ammonium environment was still the challenge for the stable CANON operation; but with 28 days of a high ammonium treatment combined with a sludge retention time control, the NOB overproliferated in the low ammonium operational period could be under control. Specifically, when the nitrite oxidation rate reached $8 \mathrm{~g} \mathrm{~N} / \mathrm{m}^{3} / \mathrm{h}$, the CANON system should enter the high ammonium influent operating mode. 16S rDNA high-throughput sequencing results show that the appropriate sludge discharging provided an environment favoring Candidatus Jettenia.
\end{abstract}

\section{Introduction}

Anaerobic ammonium oxidation (anammox) is a new pathway of autotrophic biological nitrogen removal for wastewater treatment with the advantages of less aeration consumption, low biomass production, and carbon savings $[1,2]$. Complete autotrophic nitrogen removal over nitrite (CANON) system, which combines anammox with partial nitrification in a single reactor, is one of the most promising methods to achieve energy neutral or even positive in wastewater treatment plants (WWTPs) [3, 4]. In this process, ammonium is first partially oxidized to nitrite by aerobic ammonium oxidizing bacteria $(\mathrm{AOB})$ through controlling dissolved oxygen (DO) at a low concentration. The residual ammonium is oxidized to nitrogen gas with the generated nitrite by anammox bacteria subsequently $[5,6]$. Compared with the traditional nitrification and denitrification systems, CANON process can be a more promising and economic technology for wastewater treatment because of $63 \%$ less oxygen consumption, no requirement of biodegradable organic carbon addition, and less $\mathrm{N}_{2} \mathrm{O}$ emissions $[5,6]$.

So far, CANON systems have been mostly applied to treat high ammonium wastewaters, such as landfill leachate, swine wastewater, and reject water in WWTPs (known as sidestream anammox) [7-12]. This is because high ammonia (as well as high free ammonia (FA)), high temperature, and a low DO control favor selecting both AOB and anammox bacteria as the dominant functional microorganisms, thus maintaining the stable partial nitrification and anammox processes. Specifically, the physiological differences between $\mathrm{AOB}$ and nitrite oxidizing bacteria (NOB) should be considered; that is, environmental factors such as $\mathrm{pH}$, temperature, FA, free nitrous acid (FNA), and DO must be controlled favoring $\mathrm{AOB}$ proliferation in the partial nitritation step to produce an anammox-suited substrate [13]. 
When treating mainstream wastewater that is characterized with low ammonium and ambient temperature, stressing NOB and maintaining the activity of anammox bacteria are the two key factors determining the CANON performance [14]. Indeed, substantial efforts have been made to optimize the treatment process for a steady performance in CANON systems when treating mainstream wastewater. Han et al. [15] used screens to separate flocs and granules in mainstream deammonification to wash out $\mathrm{NOB}$, and they found that over $80 \%$ of NOB was washed out and up to $70 \%$ of nitrogen removal efficiencies was achieved. Similarly, Malovanyy et al. [14] tried integrated fixed film activated sludge reactor for nitrogen removals from municipal wastewater using a deammonification process; by intermittent aeration with a high DO set-point (1.5 mg/L) and decreasing nonaerated time (30 min), NOB was successfully out-selected. However, other effective and operative approaches to ensure the effective nitrogen removal performance of CANON systems are still urgently required especially when treating low ammonium wastewater.

In this study, a novel operational pattern for CANON system treating low ammonium wastewater was developed by alternatively inflowing low ammonium concentration (mimic mainstream wastewater) and high ammonium concentration (mimic sidestream wastewater). The influent exchange frequency and the key controlling factors for effective CANON operation were examined. To elucidate the microbial structure of functional bacteria and their influence to the nitrogen removal performance, the composition of the bacterial communities in the CANON system during operational period was analyzed by $16 \mathrm{~S}$ rDNA high-throughput sequencing technology. The proposed operational strategy hopes to help CANON processes to be effectively applied in municipal wastewater treatment.

\section{Materials and Methods}

2.1. Reactor Configuration. A lab-scale sequencing batch reactor (SBR) with a working volume of $2.5 \mathrm{~L}$ was used in this study. The SBR was set in a thermostatic water bath to keep temperature at $30^{\circ} \mathrm{C}$. The experimental biomass in the reactor was mixed by a propeller stirrer at $100 \mathrm{rpm}$. An aeration device linked with an air pump was fixed at the bottom of the SBR to provide oxygen for partial nitrification. Air was regularly supplied to the SBR by an air pump.

2.2. Operational Strategies. An alternative low and high ammonium influent regime was adopted in the experiment. As shown in Figure 1, the whole experimental period was divided into four operational phases according to the influent ammonium concentration: Phase high I (0-60 d), Phase low I (61-148 d), Phase high II (149-256 d), and Phase low II (257-285d). Phases high I and II were operated at a high ammonium concentration (approximately $240 \mathrm{mg} \mathrm{NH}_{4}^{+}$$\mathrm{N} / \mathrm{L}$ ) while Phases low I and II (approximately $61 \mathrm{mg} \mathrm{NH}_{4}{ }^{+}-$ $\mathrm{N} / \mathrm{L}$ ) were operated at low ammonium concentration. A typical SBR cycle lasts for $4 \mathrm{~h}$ or $8 \mathrm{~h}$, respectively, at low or high influent ammonium concentrations (Table 1). By operating in an alternative low and high ammonium influent regime, the $\mathrm{NOB}$ inhibition and the dominance of $\mathrm{AOB}$ and anammox bacteria in the CANON system can be ensured.

2.3. Seed Sludge and Feeding Medium. The seeding granular sludge $(2.5 \mathrm{~L})$ for the experimental CANON system was from another CANON system treating high ammonium saline wastewater in our laboratory (Figure S1(A)) [3].

Synthetic wastewater was continuously introduced into the reactor using a peristaltic pump in the inflow period and the pump was controlled by a liquid level controller to control the water volume of $2.5 \mathrm{~L}$. The composition of the synthetic wastewater was $\mathrm{KH}_{2} \mathrm{PO}_{4} 0.05 \mathrm{~g} / \mathrm{L}, \mathrm{CaCl}_{2} 0.3 \mathrm{~g} / \mathrm{L}$, $\mathrm{MgSO}_{4} \cdot 7 \mathrm{H}_{2} \mathrm{O} \quad 0.3 \mathrm{~g} / \mathrm{L}, \quad \mathrm{NaHCO}_{3} 1.25 \mathrm{~g} / \mathrm{L}, \quad \mathrm{FeSO}_{4} \cdot 7 \mathrm{H}_{2} \mathrm{O}$ $0.00625 \mathrm{~g} / \mathrm{L}, \mathrm{Na}_{2}$ EDTA $0.00625 \mathrm{~g} / \mathrm{L}$, and $1.25 \mathrm{~mL} / \mathrm{L}$ of trace elements solution. The composition of the trace elements solution was prepared according to Lotti et al. [16]. $\mathrm{NH}_{4} \mathrm{Cl}$ was added to the feeding medium to reach a desired ammonium concentration in the influent. The $\mathrm{pH}$ was maintained at 8.0 at the beginning of each cycle by adding hydrochloric acid solution $(0.2 \mathrm{M})$ or sodium hydroxide solution $(0.2 \mathrm{M})$.

2.4. Analytical Methods. Water samples were collected and stored in a $4^{\circ} \mathrm{C}$ refrigerator until analysis. The concentrations of $\mathrm{NH}_{4}{ }^{+}-\mathrm{N}, \mathrm{NO}_{2}{ }^{-}-\mathrm{N}$, and $\mathrm{NO}_{3}{ }^{-}-\mathrm{N}$ were measured regularly according to the standard methods [17]. The DO concentration and $\mathrm{pH}$ were detected using online probes (WTW Multi350i, Germany).

2.5. Sample Collection, DNA Extraction, and PCR Amplification. Sludge samples were collected from the CANON system on days $60,79,124,125,148,257$, and 285 (the days before the change in the operating condition) and stored at $-20^{\circ} \mathrm{C}$ after centrifugation. Total genomic DNA was extracted in triplicate from each sample using the Power Soil DNA Isolation Kit (Sangon, China) according to the manufacturer's instructions. The quality of the obtained genomic DNA was examined by $1 \%(\mathrm{w} / \mathrm{v})$ agarose gel electrophoresis and concentration measured with NanoDrop spectrophotometer 2000 (Thermo Scientific, USA).

Polymerase chain reaction amplification of the V3-V4 region of the $16 \mathrm{~S}$ rDNA gene was then conducted using primers $341 \mathrm{~F}\left(5^{\prime}\right.$-CCTACACGACGCTCTTCCGATCTN- $\left.3^{\prime}\right)$ and $805 \mathrm{R}\left(5^{\prime}\right.$-GACTACHVGGGTATCTAATCC- $\left.3^{\prime}\right)$ with the reverse primer containing 6-bp barcodes to tag each sample (Majorbio Bio-Pharm Technology Co., Ltd., Shanghai China). PCR amplification and 16S rDNA high-throughput sequencing were performed according to our previous study $[3]$.

\section{Results and Discussion}

3.1. The Stabilization of the CANON System at High Influent Ammonium Concentration. The CANON system operated for 285 days, and the long-term nitrogen removal performance was shown in Figure 1. The biomass was initially cultivated with high ammonium concentration (196 $\pm 18 \mathrm{mg} / \mathrm{L}$ ) to set up the CANON system (Figure 1, Phase high I). After acclimation for 32 days, the TN removal rate 
TABLE 1: Operating parameters of the CANON system.

\begin{tabular}{|c|c|c|c|c|}
\hline Phase & High I & Low I & High II & Low II \\
\hline Periods (d) & $0-60$ & $61-148$ & $149-256$ & $257-285$ \\
\hline Cycle time (h) & 8 & 4 & 8 & 4 \\
\hline Influent FA (mg N/L) & $5-7$ & $<3$ & $7-10$ & $<3$ \\
\hline Influent $\mathrm{NH}_{4}{ }^{+}-\mathrm{N}(\mathrm{mg} / \mathrm{L})$ & $196 \pm 18$ & $77 \pm 4.5$ & $240 \pm 21$ & $61 \pm 5.6$ \\
\hline $\begin{array}{l}\text { Volumetric exchange } \\
\text { ratio }\end{array}$ & & 0.5 & & \\
\hline $\mathrm{DO}\left(\mathrm{mg} \mathrm{O}_{2} / \mathrm{L}\right)$ & $0.2-0.4$ & $0.2-0.4$ & $0.2-0.4$ & $0.4-0.6$ \\
\hline Temperature $\left({ }^{\circ} \mathrm{C}\right)$ & 30 & 30 & 30 & 30 \\
\hline Aeration mode & $\begin{array}{c}3 \text { aeration and anoxic stages } \\
\text { in one } \mathrm{SBR} \text { cycle } \\
\text { ( } 35 \mathrm{~min} / 105 \mathrm{~min}, \\
\text { respectively) }\end{array}$ & $\begin{array}{l}\text { 50-min aeration stage in } \\
\text { one SBR cycle }\end{array}$ & $\begin{array}{c}3 \text { aeration and anoxic stages } \\
\text { in one } \mathrm{SBR} \text { cycle } \\
(60 \mathrm{~min} / 60 \mathrm{~min}, \\
\text { respectively })\end{array}$ & $\begin{array}{c}50 \text {-min aeration stage in } \\
\text { one SBR cycle }\end{array}$ \\
\hline
\end{tabular}

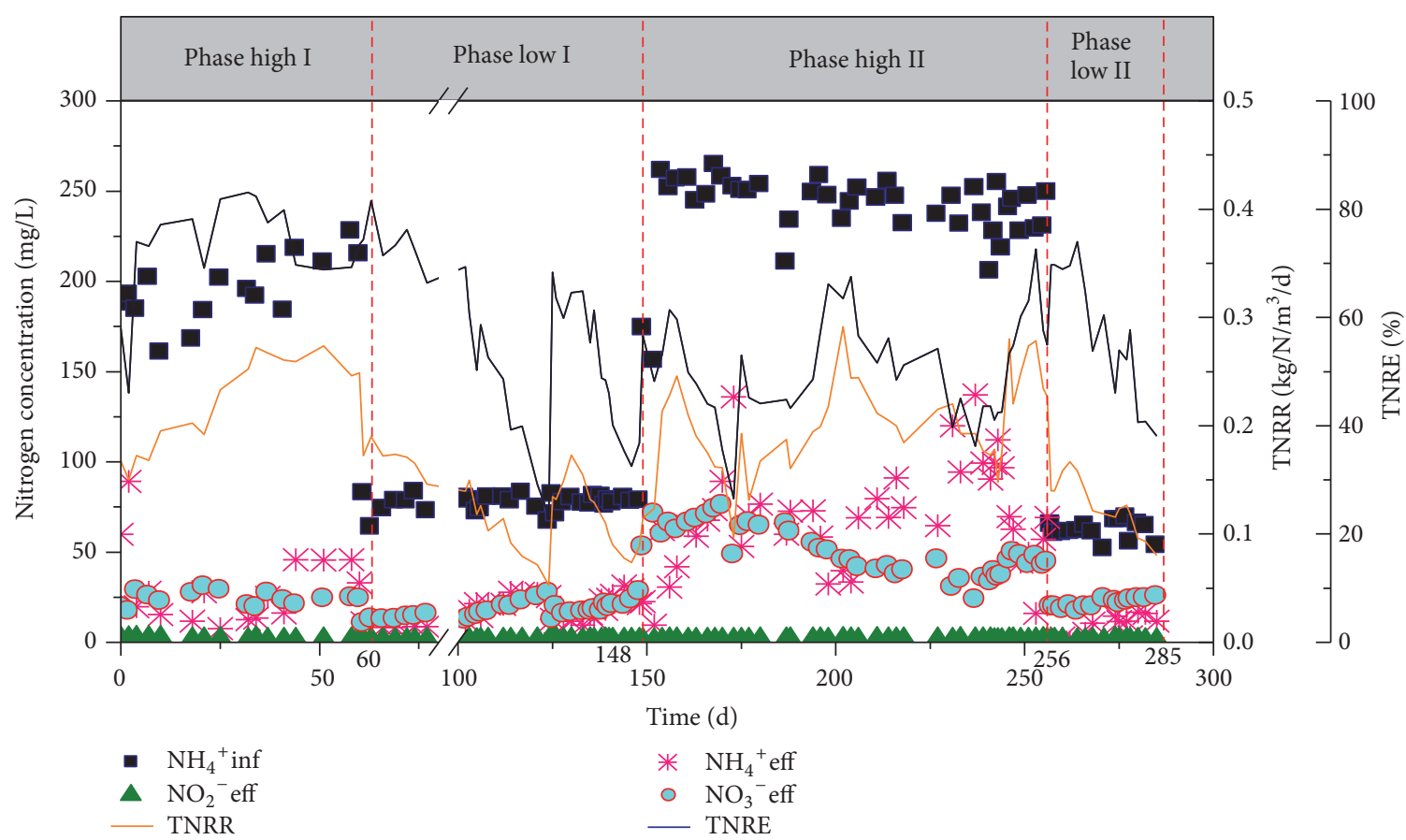

FIGURE 1: Profiles of nitrogen compounds (expressed as influent ammonium concentration, effluent ammonium concentration, effluent nitrite concentration, and effluent nitrate concentration), total nitrogen removal rate (TNRR), and total nitrogen removal efficiency (TNRE) of the CANON system over 285 days of operation.

(TNRR) and efficiency (TNRE) reached $15.1 \mathrm{~g} \mathrm{~N} / \mathrm{m}^{3} / \mathrm{h}$ and $80 \%$, respectively.

Thereafter (days 32-60), the TNRE decreased to $70 \%$ as the influent $\mathrm{NH}_{4}{ }^{+}-\mathrm{N}$ concentration increased, but the TNRR remained stable at approximately $0.26 \mathrm{~kg} \mathrm{~N} / \mathrm{m}^{3} / \mathrm{d}$, indicating that the studied CANON system had achieved steadystate nitrogen removal performance (Figure 1). Also, the ammonium oxidation rate (AOR) and the TN removal rate during the aeration stage (NRR) reached $21.2 \mathrm{~g} \mathrm{~N} / \mathrm{m}^{3} / \mathrm{h}$ and $0.26 \mathrm{~kg} \mathrm{~N} / \mathrm{m}^{3} /$ day, respectively, and nitrite oxidation rate
(NOR) was below $3 \mathrm{~g} \mathrm{~N} / \mathrm{m}^{3} / \mathrm{h}$, suggesting that the $\mathrm{NOB}$ proliferation had been controlled.

3.2. The CANON Performance Operated at Alternative Low and High Ammonium Concentrations. After a stable nitrogen removal performance was achieved in Phase high I, the CANON system adopted an alternative low and high ammonium concentration inflowing mode, that is, Phase low I and Phase high II (Figure 1). 


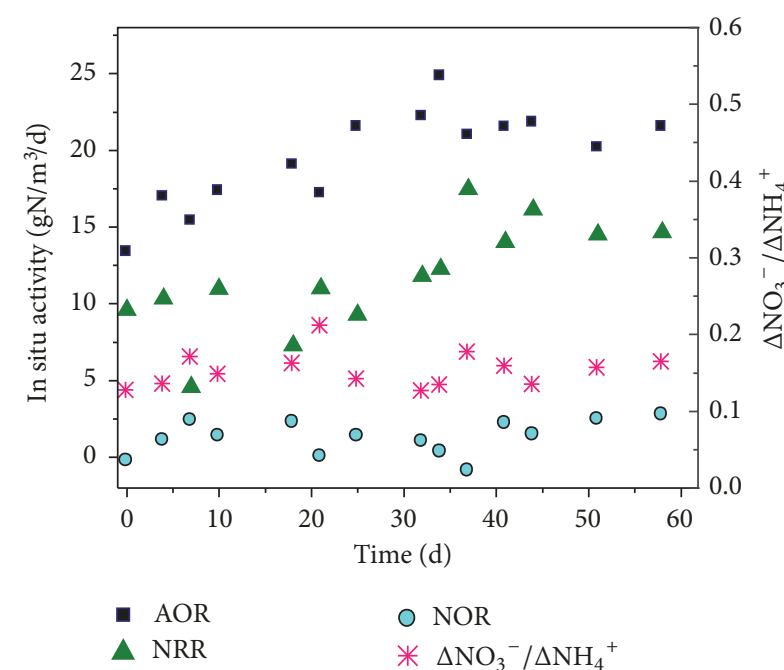

(a)

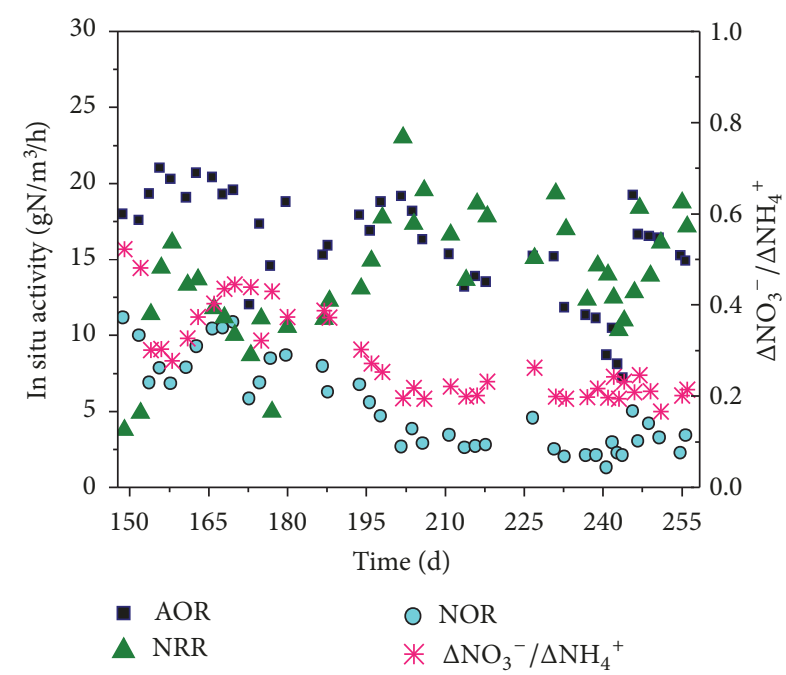

(c)

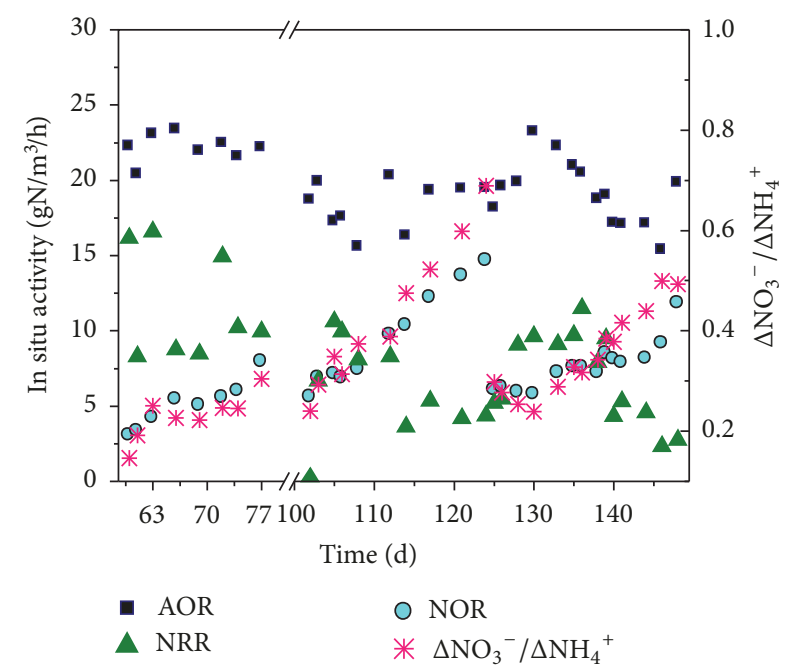

(b)

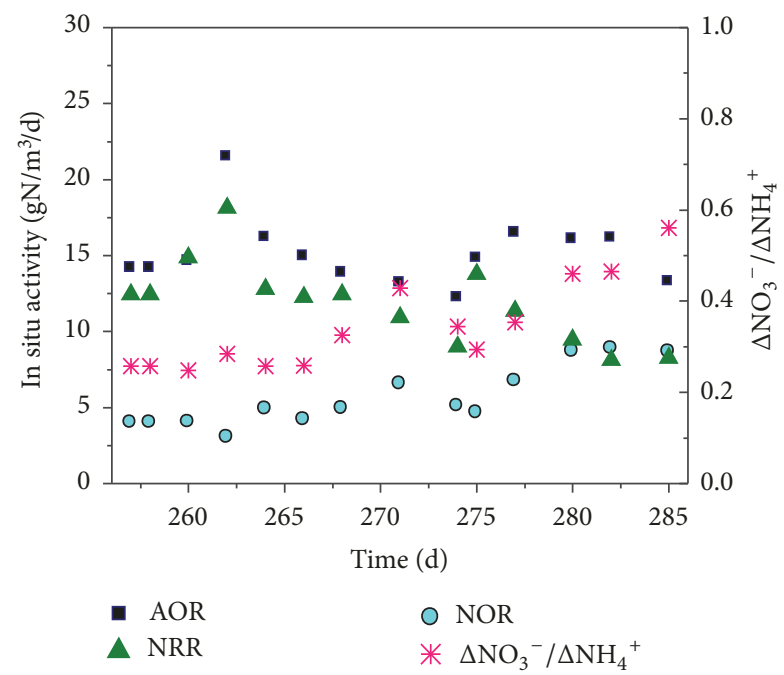

(d)

FIGURE 2: Changes in AOR, NOR, NRR, and $\Delta \mathrm{NO}_{3}{ }^{-} / \Delta \mathrm{NH}_{4}{ }^{+}$ratio of the CANON system over the whole operational duration ((a) Phase high I; (b) Phase low I; (c) Phase high II; (d) Phase low II).

\subsubsection{Operating at a Low Ammonium Concentration in Phase Low I}

(1) Variations in Nitrogen Removal Performance. After the influent ammonium decreased, the nitrogen removal performance of the CANON system was stable firstly (days 61-74) and decreased thereafter (days 77-148) (Figure 1). Specifically, when the influent $\mathrm{NH}_{4}{ }^{+}-\mathrm{N}$ was decreased to 77 $\pm 4.5 \mathrm{mg} / \mathrm{L}$ on day 61 , the TNRR immediately decreased from $0.26 \mathrm{~kg} \mathrm{~N} / \mathrm{m}^{3} / \mathrm{d}$ (day 60 ) to $0.17 \mathrm{~kg} \mathrm{~N} / \mathrm{m}^{3} / \mathrm{d}$ (day 61) with a decrease percentage of $32 \%$. Luckily, the AOR was still stable at $22 \mathrm{~g} \mathrm{~N} / \mathrm{m}^{3} / \mathrm{h}$ for about 10 days at low influent ammonium concentration, even being slightly higher than $21.2 \mathrm{~g} \mathrm{~N} / \mathrm{m}^{3} / \mathrm{h}$ in Phase high I (Figures 2(a) and 2(b)). In contrast, NRR dropped to $11 \mathrm{~g} \mathrm{~N} / \mathrm{m}^{3} / \mathrm{h}$, being lower than $15.1 \mathrm{~g} \mathrm{~N} / \mathrm{m}^{3} / \mathrm{h}$ of Phase high $\mathrm{I}$, indicating that the low influent $\mathrm{NH}_{4}{ }^{+}-\mathrm{N}$ concentration had a greater impact on anammox reaction than on ammonia oxidation reaction.

Notably, NOR increased gradually to approximately 4.9 $\mathrm{g} \mathrm{N} / \mathrm{m}^{3} / \mathrm{h}$ during days $61-74$ at a low ammonium influent (Figure 2(b)), suggesting that anammox bacteria could not compete with NOB for nitrite under the low influent $\mathrm{NH}_{4}{ }^{+}$$\mathrm{N}$ concentration operation [6]. As the inhibitory threshold of FA for AOB and NOB is 8-120 mg N/L and 0.08-0.82, respectively [18], NOB are generally more sensitive to FA than AOB and can be outcompeted by AOB under a high ammonium environment (generally high FA as well). However, as shown in Table 1 , at low $\mathrm{NH}_{4}{ }^{+}-\mathrm{N}$ concentrations, the competitive capacity of $\mathrm{AOB}$ for oxygen was not much greater than that of NOB due to the low FA (below $3 \mathrm{mg} \mathrm{N} / \mathrm{L}$ ) in Phase low I in this study. Nevertheless, during days $61-74$ in Phase low I, the TNRE of the CANON was stable at $75 \%$ as a whole. Also, when compared with Phase high I, $\Delta \mathrm{NO}_{3}{ }^{-} / \Delta \mathrm{NH}_{4}{ }^{+}$increased 
but was stable at approximately 0.23 (Figure 2(b)), indicating that the NOB abundance or activities were stable during these 14 days.

During days 74-124 (Phase low I), the nitrogen removal performance of the CANON continuously decreased (Figure 1). For instance, the TNRR and TNRE decreased to $0.05 \mathrm{~kg} \mathrm{~N} / \mathrm{m}^{3} / \mathrm{d}$ and $23 \%$, respectively. Although the AOR was still stable at $18 \mathrm{~g} \mathrm{~N} / \mathrm{m}^{3} / \mathrm{h}$, the NOR increased sharply to 14.6 $\mathrm{g} \mathrm{N} / \mathrm{m}^{3} / \mathrm{h}$ with the $\Delta \mathrm{NO}_{3}{ }^{-} / \Delta \mathrm{NH}_{4}{ }^{+}$being high at 0.69 (Figure $2(\mathrm{~b}))$. Also, the nitrate concentration in the effluent increased to $27.4 \mathrm{mg} / \mathrm{L}$ (Figure 1). This is possibly because anammox bacteria was not able to compete with NOB for nitrite at a low influent $\mathrm{NH}_{4}{ }^{+}-\mathrm{N}$ concentration, which untimely exposed anammox bacteria to a famine scenario.

It should be noted that the CANON reactor was shut down from days 78 to 101 because of the time controlling breakdown. Then the NOR increased sharply from $5.57 \mathrm{~g} \mathrm{~N} / \mathrm{m}^{3} / \mathrm{h}$ on $102 \mathrm{~d}$ to $14.6 \mathrm{~g} \mathrm{~N} / \mathrm{m}^{3} / \mathrm{h}$ on $124 \mathrm{~d}$ (Figure 2(b)). Considering that $\mathrm{NOB}$ and $\mathrm{AOB}$ are prone to colony in flocs, and anammox bacteria tends to be aggregated as granules, we meshed the activated sludge of the CANON system, to quickly recover the CANON performance. Specifically, $1 \mathrm{~L}$ mixed liquid was drawn from the CANON reactor, and the flocs were removed using a screen with 80 mesh. The left granules were poured into the CANON reactor again with $1 \mathrm{~L}$ shortcut nitrifying sludge (mainly containing AOB) from a shortcut nitration reactor in our laboratory.

After 7 days' recovery (day 130), the TNRR and TNRE increased to $0.17 \mathrm{~kg} \mathrm{~N} / \mathrm{m}^{3} / \mathrm{d}$ and $64.5 \%$, respectively (Figure 1). The AOR remained constant because of the low DO $(0.2-0.4 \mathrm{mg} / \mathrm{L})$ but NOR decreased by $60 \%$ from $14.6 \mathrm{~g} \mathrm{~N} /$ $\mathrm{m}^{3} / \mathrm{h}$ (day 124 in Phase low I) to $6 \mathrm{~g} \mathrm{~N} / \mathrm{m}^{3} / \mathrm{h}$ (day 130). The NRR increased to $9.6 \mathrm{~g} \mathrm{~N} / \mathrm{m}^{3} / \mathrm{h}$ and $\Delta \mathrm{NO}_{3}{ }^{-} / \Delta \mathrm{NH}_{4}{ }^{+}$ decreased to 0.24 with decreasing NOR (Figure 2(b)). This result suggests that it was suitable to washout $\mathrm{NOB}$ and recover the nitrogen removal performance in a short time through removing the flocs, as $\mathrm{AOB}$ and $\mathrm{NOB}$ are mainly colonized in flocs [15].

After day 130 in Phase low I, the CANON reactor deteriorated again (Figure 1). Notably, the NOR increased to $8 \mathrm{~g} \mathrm{~N} / \mathrm{m}^{3} / \mathrm{h}$ on day 140 and to $11.8 \mathrm{~g} \mathrm{~N} / \mathrm{m}^{3} / \mathrm{h}$ on day 148 (Figure 2(b)). Meanwhile, TNRE decreased to $36.8 \%$ and $\Delta \mathrm{NO}_{3}{ }^{-} / \Delta \mathrm{NH}_{4}{ }^{+}$increased to 0.5 (Figure 2(b)), indicating that NOB had proliferated again and competed nitrite with anammox bacteria. It seems that controlling only DO at a low level could not sustain a steady shortcut nitrification [19].

(2) The NOR Variation Characteristics. Remarkably, there was a linear relationship between NOR and operational days that NOR increased linearly with the operational days (Figure 3 ). When NOR was below $8 \mathrm{~g} \mathrm{~N} / \mathrm{m}^{3} / \mathrm{h}$, the NOR was gradually increased along with the operational days with a slope of 0.39 . However, after NOR was beyond $8 \mathrm{~g} \mathrm{~N} / \mathrm{m}^{3} / \mathrm{h}$, the NOR sharply increased with a slope of 0.98 until the CANON SBR completely collapsed. It seems that the NOR should be controlled under $8 \mathrm{~g} \mathrm{~N} / \mathrm{m}^{3} / \mathrm{h}$ to ensure the stable nitrogen removal performance of the studied CANON system. Thus,

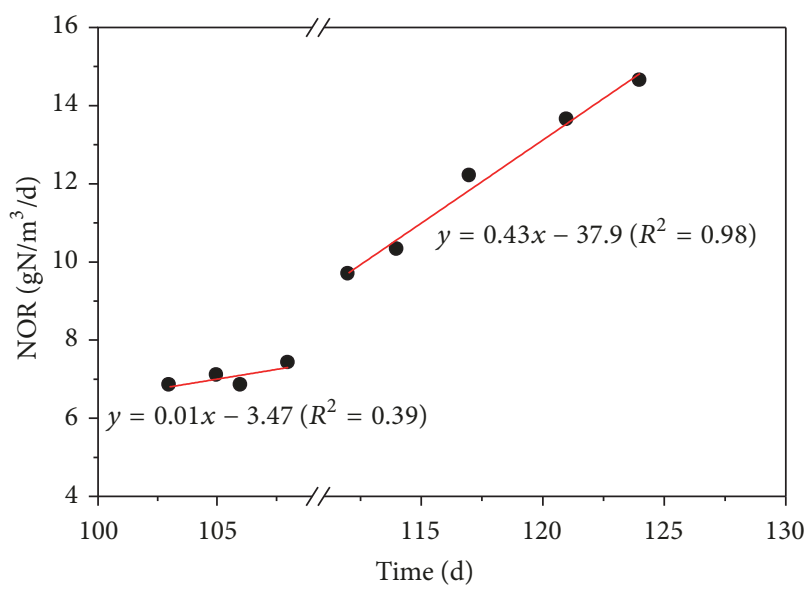

FIGURE 3: Linear fittings of NOR and time of the CANON reactor during the operation of days 103-108 and days 112-124 of Phase low I.

NOR was selected as an indicting parameter for CANON operated at a low ammonium concentration.

3.2.2. Operating at a High Ammonium Concentration in Phase High II. On day 149, the influent ammonium concentration was increased to $240 \pm 21 \mathrm{mg} / \mathrm{L}$ again to recover the CANON performance (Figure 1, Phase high II). The $\mathrm{pH}$ in the inflow was still controlled at 8.0, and the influent FA concentration was about 7-10 $\mathrm{mg} \mathrm{N} / \mathrm{L}$. By improving the FA concentration, we expected to stress the NOB proliferation and recover the functional bacteria such as AOB and anammox bacteria in the studied CANON. Corresponding to the increased influent ammonium, the aeration time increased by $80 \%$ from $300 \mathrm{~min}$ to $540 \mathrm{~min}$ for one day with the unchanged DO concentration at $0.2-0.4 \mathrm{mg} / \mathrm{L}$. Then, both the FA and DO concentrations set in Phase high II were favorable to inhibition of NOB [18, 20, 21].

(1) The Stable Nitrogen Removal Performance at High Ammonium Concentration. During day 149 to day 158 when operating at a high ammonium concentration of approximately $240 \mathrm{mg} / \mathrm{L}$, the nitrogen removal performance of the CANON system continued to increase with the TNRR and NRR up to $0.25 \mathrm{~kg} \mathrm{~N} / \mathrm{m}^{3} / \mathrm{d}$ and $16.1 \mathrm{~g} \mathrm{~N} / \mathrm{m}^{3} / \mathrm{h}$, respectively, on day 158 (Figures 1 and 2(c)). Correspondingly, the NOR and $\Delta \mathrm{NO}_{3}{ }^{-} / \Delta \mathrm{NH}_{4}{ }^{+}$decreased to $6.7 \mathrm{~g} \mathrm{~N} / \mathrm{m}^{3} / \mathrm{h}$ (below $8 \mathrm{~g} \mathrm{~N} / \mathrm{m}^{3} / \mathrm{h}$ ) and 0.28 , respectively (Figure $2(\mathrm{c})$ ), indicating that NOB had been effectively inhibited at the high ammonium concentration, and then anammox bacteria could compete with NOB for nitrite.

However, the nitrogen removal performance of the CANON system decreased from day 159 (Figure 1). Specifically, the NRR decreased to $10 \mathrm{~g} \mathrm{~N} / \mathrm{m}^{3} / \mathrm{h}$ on day 170 , and the NOR and $\Delta \mathrm{NO}_{3}{ }^{-} / \Delta \mathrm{NH}_{4}{ }^{+}$increased to $10.7 \mathrm{~g} \mathrm{~N} / \mathrm{m}^{3} / \mathrm{h}$ and 0.45 , respectively (Figure $2(\mathrm{c})$ ). These results illustrate that NOB might have been adapted to the high FA and proliferated again even at the high ammonia environment [22]. Our results are somewhat in contrast to those of Wang and Gao 
[23], who recovered the CANON system in 56 days from the excessive multiplication of NOB using simultaneous high ammonium and nitrite concentration in the inflow. The different results observed in this study with other studies are possible due to the fact that it was difficult to keep the high nitrite in the studied CANON system, as nitrite produced by AOB could be simultaneously or promptly be assumed by anammox bacteria in the CANON operational mode.

(2) SRT Adjustment to Washout NOB. Once the over proliferated NOB occurred in the CANON system, it is difficult to inhibit NOB due to the low decay rate of NOB [24]. This problem can be resolved by discharging the NOB sludge [8]. For example, in Strass WWTP (Austria), separation of AOB, NOB and anammox bacteria was handled by a hydrocyclone, and washing out NOB was effectively achieved by controlling of the selected SRT of AOB and anammox bacteria $[25,26]$. Mimicking this case, from day 175 , sludge discharging was adopted to the CANON system to control the SRT of approximately $60 \mathrm{~d}$. Then, during days $175-202$, the TNRR and TNRE increased to $0.29 \mathrm{~kg} \mathrm{~N} / \mathrm{m}^{3} / \mathrm{d}$ and $63.5 \%$ (day 202) (Figure 1), respectively; the NOR decreased to $2.6 \mathrm{~g} \mathrm{~N} / \mathrm{m}^{3} / \mathrm{h}$ with the effluent nitrate concentration decreased from $64.2 \mathrm{mg} / \mathrm{L}$ (day 175 ) to $45.6 \mathrm{mg} / \mathrm{L}$ (day 202) (Figures 1 and 2(c)). Also, the $\Delta \mathrm{NO}_{3}{ }^{-} / \Delta \mathrm{NH}_{4}{ }^{+}$decreased to 0.2 on day 202 , and NRR increased to $23 \mathrm{~g} \mathrm{~N} / \mathrm{m}^{3} / \mathrm{h}$ (Figure 2(c)).

Although a part of NOB was washed out by the sludge discharging, the AOR also decreased due to the loss of the activated sludge. Consequently, the TNRR decreased gradually with further discharge of sludge. Specifically, the AOR and NRR decreased to $13.4 \mathrm{~g} \mathrm{~N} / \mathrm{m}^{3} / \mathrm{h}$ and $17.8 \mathrm{~g} \mathrm{~N} / \mathrm{m}^{3} / \mathrm{h}$, respectively, on day 218 (Figure 2(c)). As shown in Figure S2, the MLVSS of the studied reactor decreased gradually due to over discharge of the sludge. As a result, the amount and activity of $\mathrm{AOB}$ and anammox bacteria decreased. However, because NOB was less abundant in the biomass than $\mathrm{AOB}$ and anammox bacteria, sludge discharging would lead to a lower percentage of NOB in the residual CANON system. Therefore, the NOR was still stable at $2.6 \mathrm{~g} \mathrm{~N} / \mathrm{m}^{3} / \mathrm{h}$ (far below $8 \mathrm{~g} \mathrm{~N} / \mathrm{m}^{3} / \mathrm{h}$ ) and $\Delta \mathrm{NO}_{3}{ }^{-} / \Delta \mathrm{NH}_{4}{ }^{+}$was also stable at 0.2 during days 202-218 (Figure 2(c)). To prevent the continued decrease in the TNRR, the sludge discharging was stopped on day 219 (Figure 1). With increasing MLVSS during days 219-256, the TNRR and TNRE were increased to $0.23 \mathrm{~kg} \mathrm{~N} / \mathrm{m}^{3} / \mathrm{d}$ and $55 \%$ on day 256 (Figure 1), and the NOR and $\Delta \mathrm{NO}_{3}{ }^{-} / \Delta \mathrm{NH}_{4}{ }^{+}$ could be stable at $3.3 \mathrm{~g} \mathrm{~N} / \mathrm{m}^{3} / \mathrm{h}$ and 0.2 (Figure 2(c)), respectively.

Taken together, our results show that high ammonium concentration $(240 \mathrm{mg} / \mathrm{L})$ and controlled SRT (60 day) could improve the performance of CANON system through decreasing $\mathrm{NOB}$ to a low abundance in 28 days (days 175-202).

3.2.3. Stability of the CANON System in a Low Ammonium Concentration in Phase Low II. After day 257 (in Phase low II), the ammonium concentration was decreased to $61 \pm$ $5.6 \mathrm{mg} / \mathrm{L}$ again (Figure 1) to examine the stability of CANON system at low ammonium concentrations. During day 257 to day 266 (approximately 10 days), the performance of the CANON system was stable. TNRR and TNRE were stable at $0.15 \mathrm{~kg} \mathrm{~N} / \mathrm{m}^{3} / \mathrm{d}$ and $70 \%$ (Figure 1), respectively. However, after day 267 , the CANON system deteriorated again; that is, the TNRR was lower than $0.1 \mathrm{~kg} \mathrm{~N} / \mathrm{m}^{3} / \mathrm{d}$ and NOR increased to $8 \mathrm{~g} \mathrm{~N} / \mathrm{m}^{3} / \mathrm{h}$ after day 279 (Figures 1 and 2(d)). The operational results during Phase low II confirmed that the system would deteriorate once NOR reached $8 \mathrm{~g} \mathrm{~N} / \mathrm{m}^{3} / \mathrm{h}$.

In summary, in Phase low I (day 61-74) and Phase low II (day 257-266) the CANON system could be stably operated for approximately 10 days at low ammonium concentrations $(60 \mathrm{mg} / \mathrm{L})$ with a relatively high TNRE $(70 \%)$ and low effluent $\mathrm{N}$ concentrations ( $5 \mathrm{mg} \mathrm{NH}_{4}{ }^{+}-\mathrm{N} / \mathrm{L}$ and $20 \mathrm{mg} \mathrm{TN} / \mathrm{L}$ ) (Figure 1).

\subsubsection{Microbial Composition and Structure Variations with Cyclic Low and High Influent Ammonium}

(1) Bacterial Community Composition. The composition of the bacterial communities in the CANON system was analyzed by $16 \mathrm{~S}$ rDNA high-throughput sequencing. At phylum level, the CANON system was dominated by Chloroflexi, Proteobacteria, Planctomycetes, and Chlorobi (Figure 4(a)). Anammox bacteria and $\mathrm{AOB}$, the functional bacteria in the CANON system, were affiliated to Planctomycetes and Proteobacteria, respectively. Chloroflexi and Chlorobi were also extensively detected in other anammox systems [27], and Chloroflexi could provide structure support for sludge granulation using the decayed anammox biomass $[28,29]$.

The N-related bacteria were Nitrosomonas-affiliated AOB, Nitrospira-affiliated NOB, and "Candidatus Jettenia" anammox bacteria (Figure 4(b)). Chu et al. [30] also found that "Candidatus Jettenia" and Nitrosomonas were the dominant functional bacteria in their CANON system treating high ammonium wastewater $\left(500 \mathrm{mg} \mathrm{N} \mathrm{L}^{-1}\right)$, with the relative abundances $16.8 \%$ and $20.1 \%$, respectively. It should be noted that there also existed Denitratisoma-affiliated denitrifying bacteria in the CANON system. Denitratisoma was reported to be able to use 17b-oestradiol as the sole carbon source and energy and electron donor to reduce nitrite to nitrous oxide [31].

(2) The Variations of N-Transformation Microorganisms. In order to elucidate the variations in the abundances of the $\mathrm{N}$ related bacterium, Candidatus Jettenia, Candidatus Kuenenia, Nitrosomonas, and Nitrospira were plotted in Figure 4(c). When the CANON system was stable in Phase high I (day 60), Candidatus Jettenia and Candidatus Kuenenia were the dominant anammox bacteria with the relative abundances of $3.56 \%$ and $6.9 \%$, respectively. However, when the ammonium concentration decreased in Phase low I, Candidatus Jettenia outcompeted Candidatus Kuenenia and became the main anammox genera (day 79). Specifically, from day 124 to day 148 in Phase low I, the relative abundance of Candidatus Jettenia increased from $5.91 \%$ to $14.4 \%$. This is primarily because the increased $\mathrm{AOB}$ amount and decreased $\mathrm{NOB}$ amount after sludge changing caused the increased nitrite concentration. 

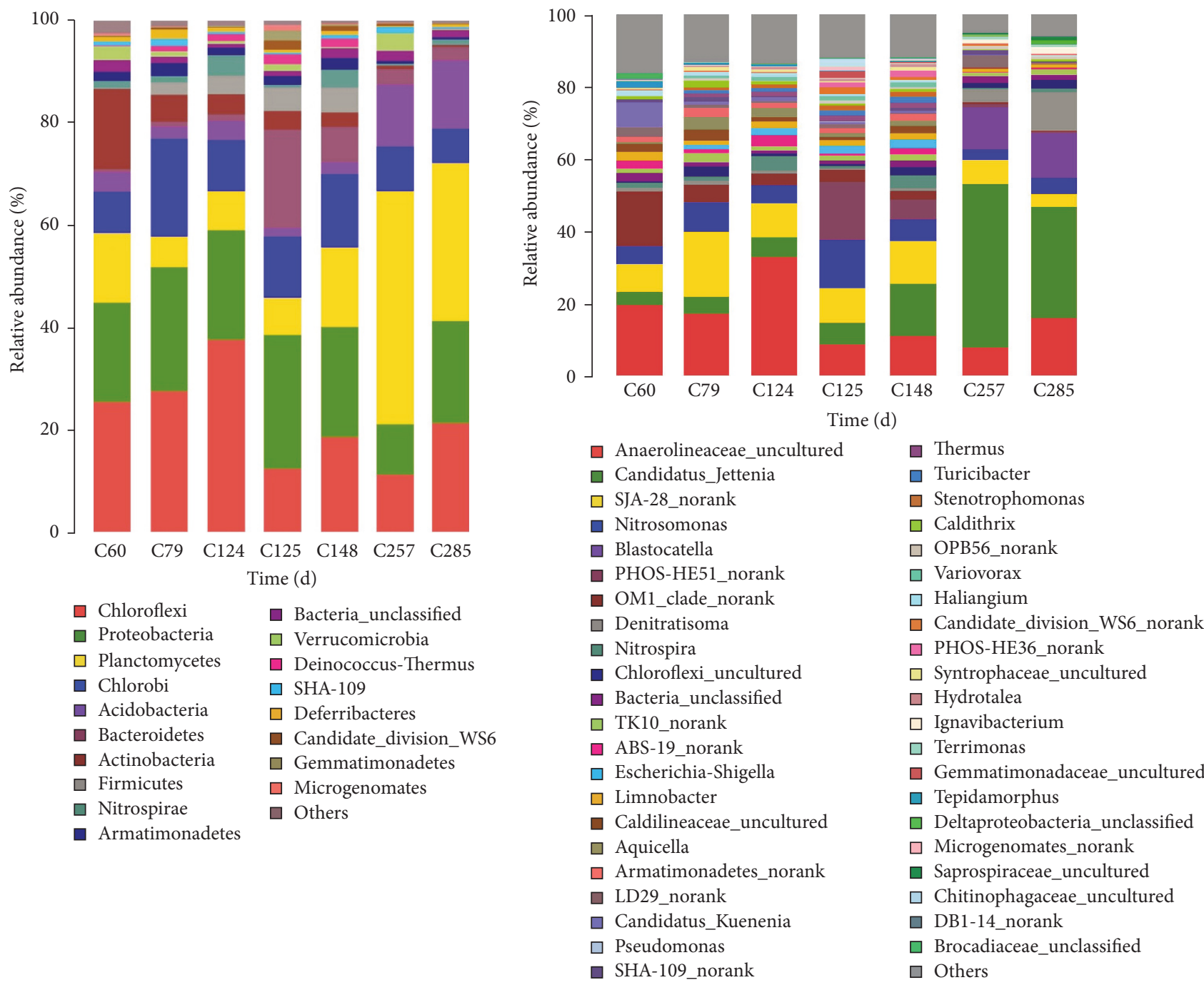

(a)

(b)

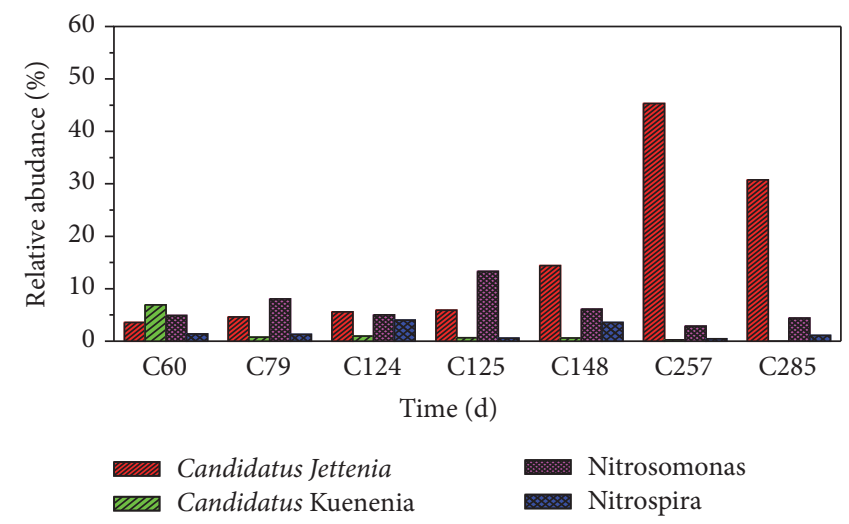

(c)

FIGURE 4: The microbial community taxonomic compositions in the studied CANON system: (a) at the phylum level; (b) at the genus level; (c) changes in the relative abundance of Candidatus Jettenia, Candidatus Kuenenia, Nitrosomonas, and Nitrospira. 
After being cultivated during Phase high II, Candidatus Jettenia was still the dominant anammox bacteria (days 257-285), while the relative abundance of Candidatus Kuenenia was at an extremely low level $(0.25 \%$ and $0.02 \%$ on days 257 and 285, respectively). For example, the relative abundance of Candidatus Jettenia increased from 14.4\% (day 148, Phase low I) to $45.32 \%$ (day 257, Phase high II). Obviously, a high ammonium concentration had favored to enrich anammox bacteria. As each genus of anammox bacteria has its own special ecological niche [32], the higher relative abundance of Candidatus Jettenia than that of Candidatus Kuenenia indicates that the present experimental condition was more suitable for Candidatus Jettenia.

As shown in Figure 4(c), on days 124 (Phase low I), 148 (Phase low I), and 285 (Phase low II), the relative abundance of Nitrospira (NOB) increased slightly because of the low ammonium concentration. However, after the sludge changing on day 124, the relative abundance of Nitrospira decreased from $4.01 \%$ (day 124) to $0.57 \%$ (day 125), and Nitrosomonas increased from $5.03 \%$ to $13.32 \%$. The relative abundance of Nitrospira also decreased from 3.55\% (day 148) to $0.43 \%$ (day 257) after being cultivated at a high ammonium concentration in Phase high II, suggesting that it was suitable to enrich $\mathrm{AOB}$ and inhibit $\mathrm{NOB}$ using sludge changing and $\mathrm{a}$ high ammonium concentration.

Compared with Phases high I and low I, Phases high II and low II seem to be more robust in the nitrogen removal performance (Figure 1), possibly because the relative abundance of anammox bacteria was high in Phases high II and low II (Figures 4(b) and 4(c)). Our results suggest that replenishing anammox bacteria biomass into the CANON system could be an alternative strategy for stabilization of anammox treatment performance.

3.3. The Recommended Operation Strategy for Practical Operation of CANON Systems. According to our experimental results, the alternative low and high ammonium influent regime was feasible for CANON system to treat a part of low ammonium wastewater. It is recommended alternatively to operate CANON system at low ammonium concentration for 10 days and at high ammonium concentration for 28 days. Also, the NOR and sludge age (SRT), as two important parameters, were recommended to be below $8 \mathrm{~g} \mathrm{~N} / \mathrm{m}^{3} / \mathrm{h}$ and approximately $60 \mathrm{~d}$ in the present CANON systems.

The proposed strategy can be realized if WWTPs have sludge digestion unit, from which the higher ammonium influent can be supplied. Also, several parallel CANON SBR units are required so that when a series CANON SBRs treat mainstream wastewater, other series can treat sidestream wastewater (i.e., sludge digestion supernatant) for enhancement of $\mathrm{AOB}$ and anammox bacteria, and inhibition of NOB. By this way, CANON system can treat nitrogen containing wastewater continuously. But to use this operational regime successfully in mainstream CANON system, the difference between actual ammonium concentration in real WWTPs and our experiment must be considered. Further research should be focused on improving the proportion of the low ammonium concentration treatment duration, and overcoming low temperature in real municipal wastewater.
Our strategy hopes to help opening a new possibility for CANON processes used in municipal wastewater (mainstream wastewater) treatment.

\section{Conclusions}

An alternative low and high ammonium influent regime was proposed and investigated to keep CANON stable when treating low ammonium wastewater. Alternatively operating at a low ammonium concentration for 10 days and at a high ammonium concentration for 28 days was feasible for CANON to treat low ammonium wastewater. NOR and sludge age, as two important parameters, should be controlled to maintain a stable operation. NOR should be kept under $8 \mathrm{~g} \mathrm{~N} / \mathrm{m}^{3} / \mathrm{h}$ to prevent CANON deterioration. To use CANON in mainstream successfully, further studies are needed to shorten the duration of operating at high ammonium concentrations and overcome low temperature.

\section{Conflicts of Interest}

The authors declare that they have no conflicts of interest.

\section{Acknowledgments}

This work was supported by the National Natural Science Foundation of China (NSFC) (51522809 and 51378370).

\section{Supplementary Materials}

Figure S1: the anammox granule of seeding CANON sludge (A); seeding CANON sludge (B); anammox granule after sieving on day $124(\mathrm{C})$; flocs after sieving on day $124(\mathrm{D})$. Figure S2: changes in the MLSS, MLVSS and $\Delta \mathrm{NO}_{3}{ }^{-} / \Delta \mathrm{NH}_{4}{ }^{+}$ ratio over the operation of Phase high II. Figure S3: rarefaction curve. Table S1: microbial community richness and diversity index of sludge samples. (Supplementary Materials)

\section{References}

[1] B. Kartal, N. M. De Almeida, W. J. Maalcke, H. J. M. Op den Camp, M. S. M. Jetten, and J. T. Keltjens, "How to make a living from anaerobic ammonium oxidation," FEMS Microbiology Reviews, vol. 37, no. 3, pp. 428-461, 2013.

[2] M. Strous, J. A. Fuerst, E. H. M. Kramer et al., "Missing lithotroph identified as new planctomycete," Nature, vol. 400, no. 6743, pp. 446-449, 1999.

[3] Y. Wang, J. Chen, S. Zhou et al., "16S rRNA gene highthroughput sequencing reveals shift in nitrogen conversion related microorganisms in a CANON system in response to salt stress," Chemical Engineering Journal, vol. 317, pp. 512-521, 2017.

[4] X. Zhang, D. Li, Y. Liang, Y. He, Y. Zhang, and J. Zhang, "Autotrophic nitrogen removal from domestic sewage in MBRCANON system and the biodiversity of functional microbes," Bioresource Technology, vol. 150, pp. 113-120, 2013.

[5] A. O. Sliekers, N. Derwort, J. L. Campos Gomez, M. Strous, J. G. Kuenen, and M. S. M. Jetten, "Completely autotrophic nitrogen removal over nitrite in one single reactor," Water Research, vol. 36 , no. 10, pp. 2475-2482, 2002. 
[6] K. A. Third, A. O. Sliekers, J. G. Kuenen, and M. S. M. Jetten, "The CANON system (completely autotrophic nitrogenremoval over nitrite) under ammonium limitation: interaction and competition between three groups of bacteria," Systematic and Applied Microbiology, vol. 24, no. 4, pp. 588-596, 2001.

[7] M. Azari, U. Walter, V. Rekers, J.-D. Gu, and M. Denecke, "More than a decade of experience of landfill leachate treatment with a full-scale anammox plant combining activated sludge and activated carbon biofilm," Chemosphere, vol. 174, pp. 117-126, 2017.

[8] A. Joss, D. Salzgeber, J. Eugster et al., "Full-scale nitrogen removal from digester liquid with partial nitritation and anammox in one SBR," Environmental Science \& Technology, vol. 43, no. 14, pp. 5301-5306, 2009.

[9] S. Lackner, E. M. Gilbert, S. E. Vlaeminck, A. Joss, H. Horn, and M. C. M. van Loosdrecht, "Full-scale partial nitritation/ anammox experiences-an application survey," Water Research, vol. 55, pp. 292-303, 2014.

[10] W. R. L. van der Star, W. R. Abma, D. Blommers et al., "Startup of reactors for anoxic ammonium oxidation: Experiences from the first full-scale anammox reactor in Rotterdam," Water Research, vol. 41, no. 18, pp. 4149-4163, 2007.

[11] T. Yamamoto, K. Takaki, T. Koyama, and K. Furukawa, "Longterm stability of partial nitritation of swine wastewater digester liquor and its subsequent treatment by Anammox," Bioresource Technology, vol. 99, no. 14, pp. 6419-6425, 2008.

[12] F. Zhang, Y. Peng, L. Miao, Z. Wang, S. Wang, and B. Li, "A novel simultaneous partial nitrification Anammox and denitrification (SNAD) with intermittent aeration for cost-effective nitrogen removal from mature landfill leachate," Chemical Engineering Journal, vol. 313, pp. 619-628, 2017.

[13] S. W. H. Van Hulle, H. J. P. Vandeweyer, B. D. Meesschaert, P. A. Vanrolleghem, P. Dejans, and A. Dumoulin, "Engineering aspects and practical application of autotrophic nitrogen removal from nitrogen rich streams," Chemical Engineering Journal, vol. 162, no. 1, pp. 1-20, 2010.

[14] A. Malovanyy, J. Trela, and E. Plaza, "Mainstream wastewater treatment in integrated fixed film activated sludge (IFAS) reactor by partial nitritation/anammox process," Bioresource Technology, vol. 198, pp. 478-487, 2015.

[15] M. Han, S. E. Vlaeminck, A. Al-Omari et al., "Uncoupling the solids retention times of flocs and granules in mainstream deammonification: A screen as effective out-selection tool for nitrite oxidizing bacteria," Bioresource Technology, vol. 221, pp. 195-204, 2016.

[16] T. Lotti, R. Kleerebezem, Z. Hu, B. Kartal, M. S. M. Jetten, and M. C. M. van Loosdrecht, "Simultaneous partial nitritation and anammox at low temperature with granular sludge," Water Research, vol. 66, pp. 111-121, 2014.

[17] APHA, Standard Methods for the Examination of Water and Wastewater, American Public Health Association, Washington, DC, USA, 21st edition, 2005.

[18] A. C. Anthonisen, R. C. Loehr, T. B. S. Prakasam, and E. G. Srinath, "Inhibition of nitrification by ammonia and nitrous acid," Journal of the Water Pollution Control Federation, vol. 48, no. 5, pp. 835-852, 1976.

[19] N. Morales, Á. Val del Río, J. R. Vázquez-Padín, R. Méndez, J. L. Campos, and A. Mosquera-Corral, "The granular biomass properties and the acclimation period affect the partial nitritation/anammox process stability at a low temperature and ammonium concentration," Process Biochemistry, vol. 51, no. 12, pp. 2134-2142, 2016.
[20] R. Blackburne, Z. Yuan, and J. Keller, "Partial nitrification to nitrite using low dissolved oxygen concentration as the main selection factor," Biodegradation, vol. 19, no. 2, pp. 303-312, 2008.

[21] Y. Ma, Y. Peng, S. Wang, Z. Yuan, and X. Wang, "Achieving nitrogen removal via nitrite in a pilot-scale continuous predenitrification plant," Water Research, vol. 43, no. 3, pp. 563-572, 2009.

[22] O. Turk and D. S. Mavinic, "Maintaining nitrite build-up in a system acclimated to free ammonia," Water Research, vol. 23, no. 11, pp. 1383-1388, 1989.

[23] X. Wang and D. Gao, "In-situ restoration of one-stage partial nitritation-anammox process deteriorated by nitrate build-up via elevated substrate levels," Scientific Reports, vol. 6, Article ID 37500, 2016.

[24] I. Jubany, J. Lafuente, J. A. Baeza, and J. Carrera, "Total and stable washout of nitrite oxidizing bacteria from a nitrifying continuous activated sludge system using automatic control based on Oxygen Uptake Rate measurements," Water Research, vol. 43, no. 11, pp. 2761-2772, 2009.

[25] B. Wett, A. Omari, S. M. Podmirseg et al., "Going for mainstream deammonification from bench to full scale for maximized resource efficiency," Water Science and Technology, vol. 68, no. 2, pp. 283-289, 2013.

[26] B. Wett, M. Hell, G. Nyhuis, T. Puempel, I. Takacs, and S. Murthy, "Syntrophy of aerobic and anaerobic ammonia oxidisers," Water Science and Technology, vol. 61, no. 8, pp. 1915-1922, 2010.

[27] X. Li, S. Sun, H. Yuan, B. D. Badgley, and Z. He, "Mainstream upflow nitritation-anammox system with hybrid anaerobic pretreatment: Long-term performance and microbial community dynamics," Water Research, vol. 125, pp. 298-308, 2017.

[28] T. Kindaichi, S. Yuri, N. Ozaki, and A. Ohashi, "Ecophysiological role and function of uncultured Chloroflexi in an anammox reactor," Water Science and Technology, vol. 66, no. 12, pp. 25562561, 2012.

[29] P. Larsen, J. L. Nielsen, D. Otzen, and P. H. Nielsen, "Amyloidlike adhesins produced by floc-forming and filamentous bacteria in activated sludge," Applied and Environmental Microbiology, vol. 74, no. 5, pp. 1517-1526, 2008.

[30] Z.-R. Chu, K. Wang, X.-K. Li, M.-T. Zhu, L. Yang, and J. Zhang, "Microbial characterization of aggregates within a one-stage nitritation-anammox system using high-throughput amplicon sequencing," Chemical Engineering Journal, vol. 262, pp. 41-48, 2015.

[31] M. Fahrbach, J. Kuever, R. Meinke, P. Kämpfer, and J. Hollender, "Denitratisoma oestradiolicum gen. nov., sp. nov., a $17 \beta$ oestradiol-degrading, denitrifying betaproteobacterium," International Journal of Systematic and Evolutionary Microbiology, vol. 56, no. 7, pp. 1547-1552, 2006.

[32] B. Kartal, J. Rattray, L. A. van Niftrik et al., "Candidatus "Anammoxoglobus propionicus" a new propionate oxidizing species of anaerobic ammonium oxidizing bacteria," Systematic and Applied Microbiology, vol. 30, no. 1, pp. 39-49, 2007. 


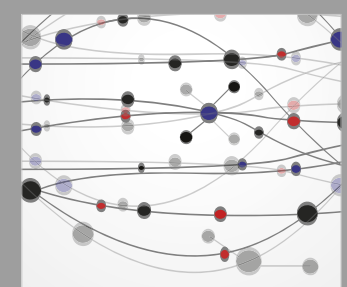

The Scientific World Journal
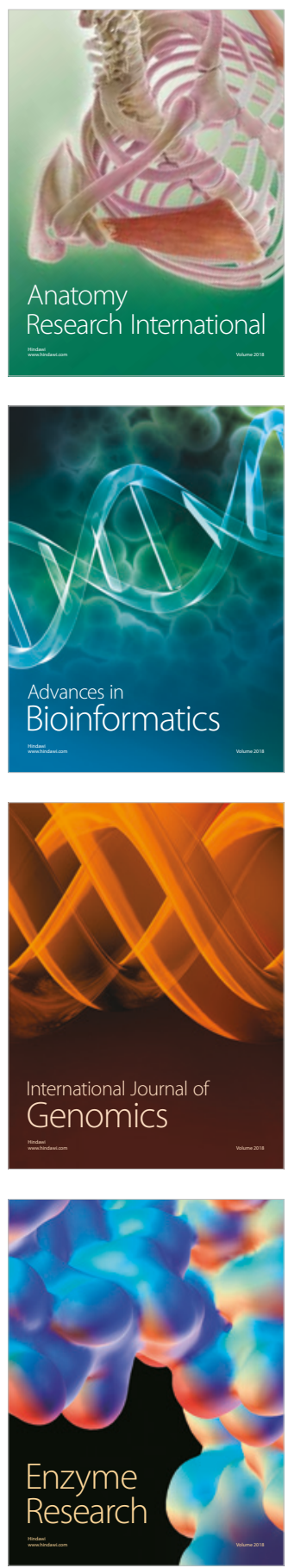
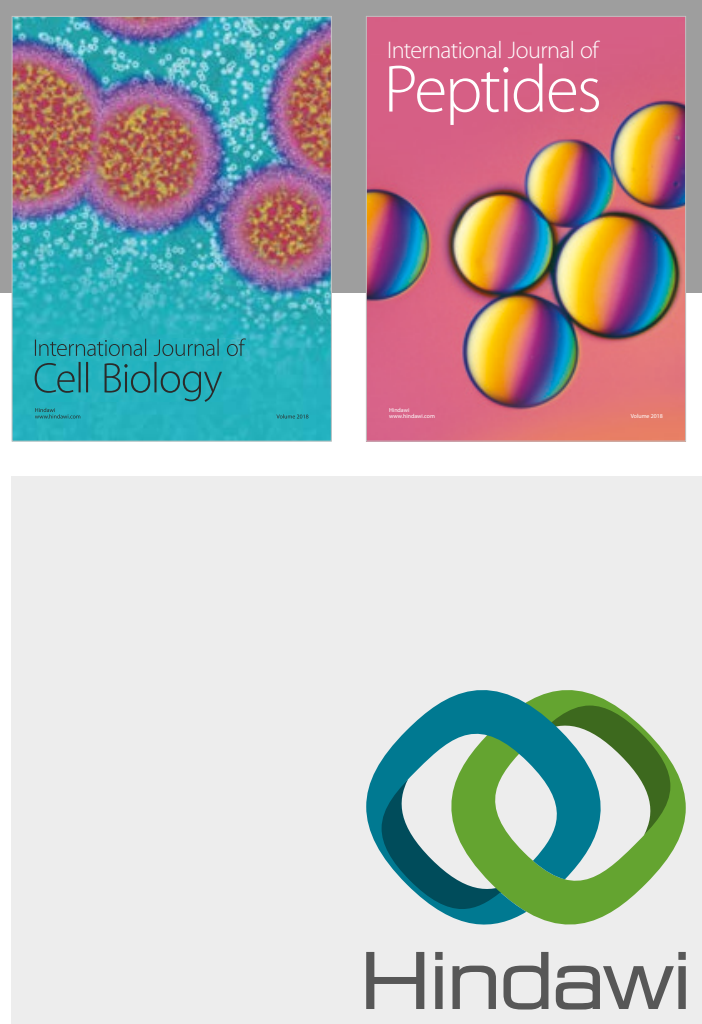

Submit your manuscripts at

www.hindawi.com
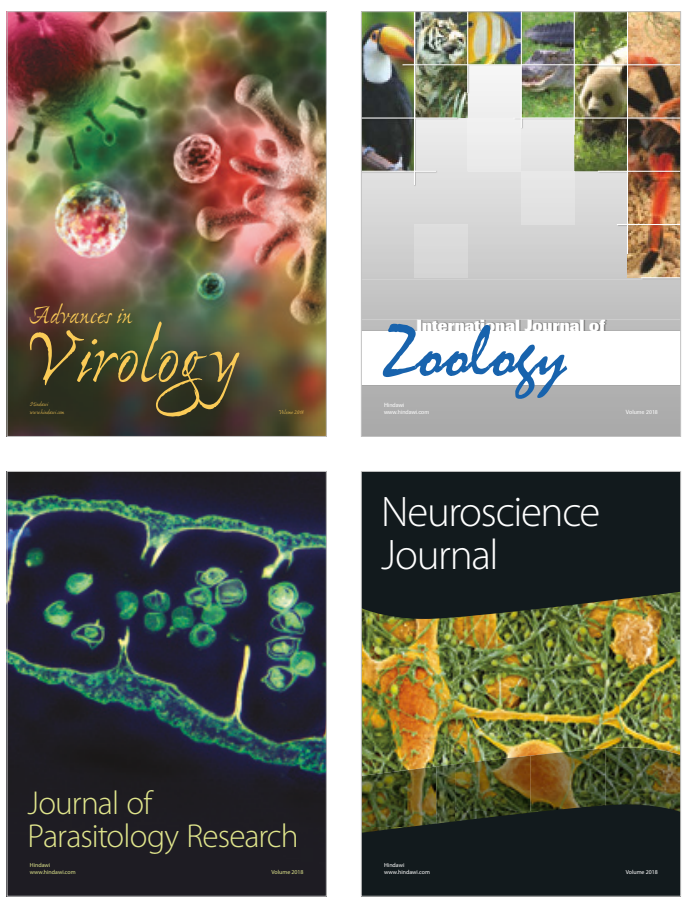
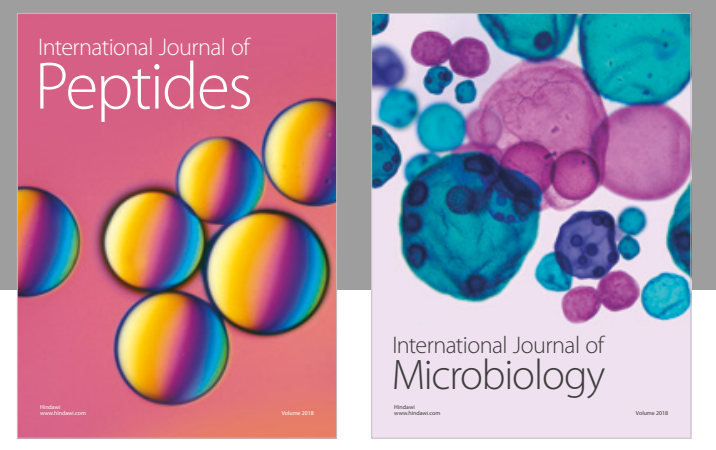

nternational Journal of Microbiology
Journal of
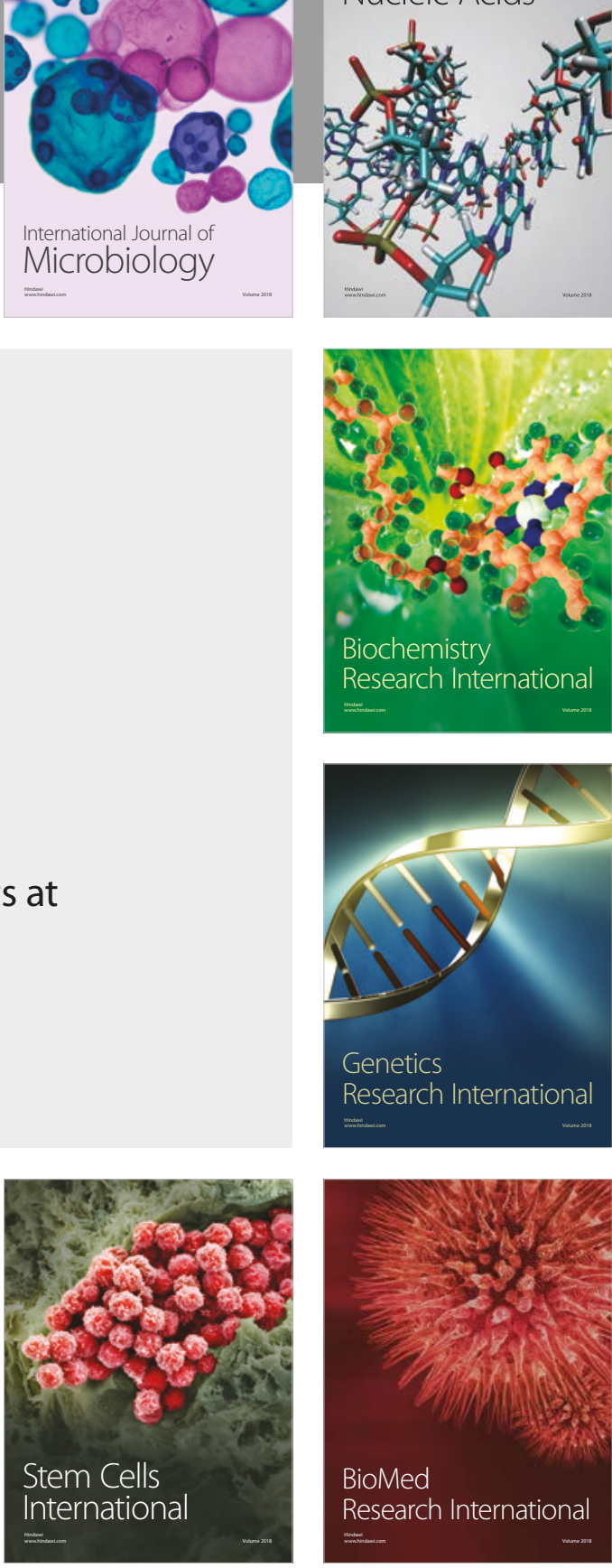
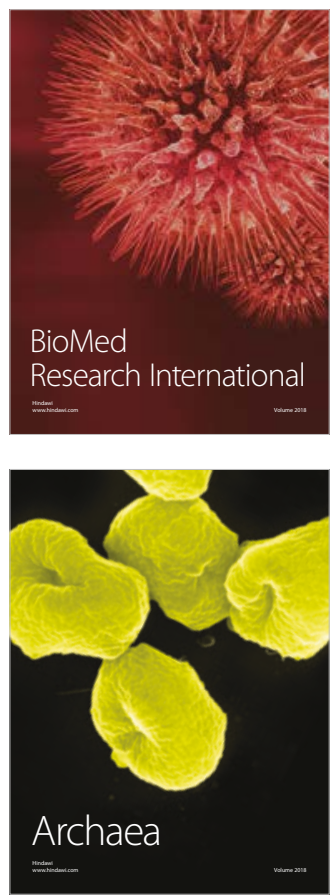